\title{
A REGIONÁLIS TUDOMÁNY ÚJ IRÁNYZATA: A PÉNZÜGYI FÖLDRAJZ
}

\author{
(The New Trend of Regional Science: Financial Geography)
}

\section{GÁL ZOLTÁN \\ Új diszciplína}

A pénzügyi földrajz vagy a pénzügyek területi gazdaságtana (Financial Geography, Regional Financial Economics) a gazdaságföldrajz illetve a regionális gazdaságtan újkeletü interdiszciplináris szubdiszciplínája, amely a pénz térbeli mozgásfolyamataival és megjelenési formáival, a pénztőkék intézményi és szabályozási (regulatív) struktúráival, illetve a pénzmozgások társadalmi és kulturális hatásaival foglakozó tudományág. A nyugati szakirodalomban már több mint másfél évtizedes múltra visszatekintö gazdaságföldrajzi, területi gazdaságtani szubdiszciplína a magyarországi szakirodalomban szinte alig vált ismertté.

A hazai közgazdasági szakirodalom elemzi ugyan a pénzủgyi szektor müködésének banküzemtani, makrogazdasági szempontjait, de nem foglakoznak a pénzügyek területi fejlódésre gyakorolt hatásával. A hazai földrajztudomány is elhanyagolja e területet, olyannyira, hogy a közelmúltban megjelent „Általános társadalomföldrajz I." címủ egyetemi tankőnyv tudomány-rendszertani fejezetébool a geográfiában központi szerepet játszó angolszász iskolák mellett a legutóbbi évtizedek új irányzatainak ismertetése - többek között a pénzügyi földrajzé - is hiányzik. A tárgykörben Magyarországon született eddigi vizsgálatok mind az MTA RKK kutatóinak nevéhez füződnek (Illés Iván, Lados Mihály, Lengyel Imre, Gál Zoltán).

A pénz földrajza iránt jelenleg mutatkozó nagyobb fokú érdeklődést a pénzügyi szolgáltatásokban és az információs technológiảban bekövetkezett robbanásszerü növekedés, illetve azok a jelentős változások, pénzügyi válságok indokolják, amelyek nem csak a pénzügyi teret formálják, de a világ pénzügyi térképét is folyamatosan átalakítják. Napjaink eröteljesen monetáris jelleget öltő világgazdaságában zajló rendkívül erós térformáló folyamatok és a reálgazdasági szféra rovására hihetetlen módon felértékelődött reáltevékenység nélküli nemzetközi pénzpiaci, illetve a régiók és nemzetgazdaságok között zajló jövedelemtranszferek rendkívüli módon indokolják a pénzügyi folyamatok geográfiai és regionális gazdaságtani vizsgálatát.

\section{Az új irányzat születése}

A gazdaságföldrajz klasszikus irányzatai döntỏen az ipari terek vizsgálatával foglalkoztak, de már az első térgazdaságtani (regionális gazdaságtani) munkákban meg-megjelent a pénzmozgások térbeli folyamatainak néhány interpretációja. August Lösch „The Economics of Location" címü munkájában figyelmet szentelt a 
gazdasági tér néhány pénzügyi aspektusának azáltal, hogy az USA példáján vizsgálta a kamatlábak, hitel és fogyasztói árindexek térbeli különbségeit (Lösch 1954). A regionális pénzügytan elsö rendszerbe foglalt megfogalmazását Gunnar Myrdal 1956-os munkájában találjuk, aki a térben zajló pénzmozgások és az egyenlótlen regionális fejlődés közötti kapcsolatoknak is figyelmet szentelt (Myrdal 1956). A regionális pénzügyi transzferek egyenlötlenségeinek okait kutatva, feltárva felhívta a figyelmet a periférikus régiókat különösen sújtó, a nemzeti bankközpont irányába ható tőkekiáramlásra, amely egyike a régiók további periferizálódását okozó „kimosó hatásoknak" (backwash effects). Myrdalnak az egyenlötlen regionális fejlödés kumulatív okait elemzö modellje közvetlenül nagy hatást gyakorolt mind a regionális gazdaságtan, mind pedig a gazdaságföldrajz fejlódésére, de csak az 1970-es évektől kezdödően, amikor is elkezdődött a regionális és városi pénzügyek gazdaságtanának tanulmányozása (Porteous 1995).

Az első vizsgálatok gazdaságtörténeti alapról közelítve vizsgálták az Egyesült Államok nemzeti pénzrendszerének kifejlődését az 1870 és az 1920-as évek közötti periódusban, hangsúlyt fektetve a regionális bankstruktúrák jellegzetes különbözöségeire, anélkül, hogy a pénzpiacok térbeli dimenzióinak és müködési sajátosságainak mélyebb feltárására sor került volna (Cohen-Maeshiro 1977; James 1976; Roberts-Fishkind 1979; Rockoff 1977).

Az 1950-es, 1960-as évtizedekben a geográfusok lényegében alig szenteltek figyelmet a monetáris témáknak, s csak az 1970-es években figyelhetö meg némi érdeklödés a térbeli pénzmozgások és azok hatásai irảnt. Kiemelhetỏek Conzen amerikai geográfus kutatásai, amelyek a pénzmozgások és a városhierarchia kapcsolatát vizsgálták. A bankközi kapcsolatokat vizsgálta az Egyesült Államokban az 1840 és 1910 közötti időszakban, úgy mint a városhálózat különbözö szintjei közötti kapcsolatok indexét. Tulajdonképpen azt elemezte, hogy a vidéki kisebb bankoknak a nagyvárosok pénzintézeteiben elhelyezett bankszámlája milyen arányban oszlott meg az egyes nagyvárosok között, illetve azt, hogy az egyes bankközpontok mekkora vonzáskörzeteket tudtak speciális bankközi kapcsolataik révén kialakítani. $\mathrm{Az}$ eredmények egy négyszintủ pénzintézeti városhierarchia létezését igazolták. Conzennek az 1970-es évek végén megjelent tanulmánya elöször bizonyította a bankhálózat és a városhierarchia közötti szoros kapcsolatot, hangsúlyozva, hogy a bankrendszeren belüli tökeáramlás térbeli dimenzióinak elemzése lehetöséget nyüjthat a városhálózat átalakulásának tanulmányozására is, mivel a városhálózaton belüli igazi szelekciót leginkább a javak, szolgáltatások, információk, és mindenekelött a pénz és a hitel körforgása indította el (Conzen 1979). A geográfusok másik csoportja leginkább az urbánus tereken belül, a különböző lakóövezetek közötti egyenlőtlen jelzáloghitel mozgásokat vizsgálta az amerikai és brit városok példáján (Harvey 1974), azonban hatásuk a későbbi vizsgálatokra, talán erős marxista politikai megközelítésük miatt mégis marginális maradt.

A Financial Geography igazán egységes kutatási irányzatának kialakulása az 1980-as évtizedben zajlott, melynek eredményeként az 1990-es évtized derekára igen sok neves szakembert, termékeny publikációs hátteret, illetve számtalan tudományos fórumot biztosító egységes tudományággá szerveződött. A tökemozgások 
makroökonómiai, banküzemtani folyamatait korábban kevéssé ismerő geográfusok, illetve a pénzmozgások térbeli dimenzióit meglehetösen elhanyagoló közgazdászok kutatásmódszertani alapokat is megteremtő munkái egyre növekvő számban jelentek meg az elmúlt évtized folyamán. A regionális gazdaságtan a regionális kamatkülönbségeket (Mckillop-Hutchinson 1991), az interregionális tőkemozgásokat (Moore-Hill 1982) és a régiók hitelellátottságát (Alessandrini 1992; Chick 1993; Zazzaro 1997) vizsgálta. Mások pedig elsősorban a nemzetközi monetáris folyamatok térbeli dimenzióit feltáró eredményeiket publikálták (Laulajainen 1998; O’Brien 1992). Szintén közgazdászok kutatásai nyomán születtek meg a pénzügyi rendszerek térbeli fejlödésének szakaszait és földrajzi struktúráit elemző elméleti munkák, amelyek részben a bankok és a hitelkihelyezések földrajzával (Dow 1987; 1988; 1990), részben pedig a pénzügyi központok fejlödésével illetve versenyével foglakoznak (Porteous 1995).

Az utóbbi években a geográfián belül is egyre nagyobb hangsúlyt kapnak a gazdasági teret formáló pénz- és tőkemozgások folyamatait feltáró elméleti és empirikus kutatások. David Harvey korábbi, már említett munkáiban a tőkemozgások egyenlótlen megoszlásának szociális válságokat gerjesztő folyamatait vizsgálta a nagyvárosi terek példáin (Harvey 1982; 1989). Ezzel egy időben egyre specializáltabb geográfiai tanulmányok foglakoztak az egyes pénzügyi intézményekkel, szolgáltatásokkal és pénzpiacokkal, így a bankokkal, kockázati tőketársaságokkal, értékpapírpiacokkal és nyugdíjalapokkal (Lee 1993; Leyshon-Thrift 1997; Martin 1989; 1994; 1999; O'Uallacháin 1994; Tickell 1996). A geográfusok harmadik csoportja a legnagyobb nemzetközi pénzközpontok (New York, London, Tokió és az off-shore központok) gazdasági, politikai és társadalmi dinamizmusának vizsgálatára irányítja figyelmét, feltárva e központok szerepét a globális pénzmozgások szervezésében, valamint vizsgálva azokat az intézményi-vállalati kultúrákat és gyakorlatokat, amelyek a pénzügyi szektorban foglalkoztatottak pozícióját meghatározzák (Corbridge-Martin-Thrift 1994; Leyshon-Thrift 1997; Sassen 1991; Thrift 1994). A geográfusok negyedik csoportja a regionális tőkeáramlások és a regionális gazdasági fejlödés kapcsolatait elemzi, figyelmet szentelve a globális és regionális struktúrák közötti kapcsolatrendszerek feltárásának, az Európai Monetáris Unió és az EU-n belül múködö regionális bankrendszerek kapcsolatának (AlessandriniZazzaro 1999; Dow 1990; Lee 1999).

A pénzügyi földrajz a bemutatott kutatási eredmények alapján az ezredfordulóra egy erősen megalapozott földrajzi résztudománnyá nőtte ki magát. Mindazonáltal még távolról sem tekinthető teljesnek a helyi, regionális pénzügyek, illetve a nemzeti és globális pénzpiacok térbeli rendszereinek kutatása, de eddig már öt monográfia és tanulmánykötet (Corbridge-Martin-Thrift 1994; Laulajainen 1998; LeyshonThrift 1997; Martin 1999; Porteous 1995) tekintette feladatának a pénzmozgások szerteágazó térbeli dimenzióinak feltárását, valamint a geográfusok és közgazdászok kutatásainak integrálását. Ennek az interdiszciplináris összefogásnak az eredményét jelzi, hogy egyre több gazdaságföldrajzos tartja fontosnak a pénzügyek tanulmányozását, illetve mind több pénzügyeket kutató közgazdász hangsúlyozza a térbeli megközelítés, a geográfiai módszerek alkalmazásának a szükségességét. 


\section{A pénz térstruktúrái}

A pénzügyi renđszerek alapvető jellemzője a térbeli meghatározottság. Ennek látszólag ellentmond az a tény, hogy a pénz térbeli mozgása - ellentétben sok más áruéval - a pénzhelyettesítók nagy száma, mozgékonysága és a konvertibilitás miatt legtöbbször térben megfoghatatlan (,,áthatatlan”), ugyanakkor a pénzügyi rendszerek olyan komplex, a pénzmozgások keretéül szolgáló intézményi, szervezeti háttérrel rendelkeznek, amely nagyon is megfoghatóvá teszi a pénz térbeli mozgását és funkcióit. A pénzügyi rendszereket alkotó intézmények és piacok természetesen tevékenységüket és mủködésüket tekintve is specializáltak, a bankok, a biztositók és a brókerházak által kezelt tőkék és pénzeszközök mozgása a különböző helyi, regionális, nemzeti, szupranacionális és nemzetközi pénzpiacokon egyidejủleg zajlik. A pénztőkék különböző funkcionális formában és intézményi kereteken, tehát a bankokon, jelzálogintézeteken, biztosítókon, nyugdíjalapokon, értékpapír és részvénypiacokon keresztül körforgásszerúen mozognak. A pénz aggregátumok különbözö befektetési, hitelezési, kereskedési és spekulációs formákon keresztül megvalósuló folyamatos „újratermelődése” mozgatja a különböző hitel és adósságállományokat a lokális piacokon, régiókon, nemzeti piacokon át egészen a nemzetközi pénzpiacokig. A pénzmozgásoknak azonban nemcsak a gazdasági, hanem a társadalmi értéke is meghatározó, mivel a termelés és a gazdasági fejlődés generálásán keresztül a társadalom, illetve egy adott helyi-regionális vagy akár nemzeti közösség egy részének foglalkoztatását, jövedelmét, jólétét is növelheti.

A pénzügyi rendszeren belül zajló körforgásnak számos további kutatásra érdemes dimenziója és faktora van.

\section{1) A pénzügyi rendszer telephely dimenziója}

A pénzügyi intézmények és a pénzpiacok térbeli megoszlásának vizsgálata nagy jelentőséggel bír, ugyanis a fejlett országokban bizonyos alapvetó pénzügyi funkciók és intézményi formák (bankok, lakáshitel-intézetek) földrajzilag sủrűbb eloszlásban vannak jelen a gazdasági térben, mint az egyéb, specializáltabb pénzpiaci funkciókintézmények (tőzsdék, nyugdíjalapok, bankközpontok, kockázati tőketársaságok), amelyekre inkább az erősebb térbeli koncentrálódás a jellemzőbb. Ugyanúgy, mint más gazdasági ágazatokra, a pénzügyekben is jellemző az agglomerálódás, a fejlödési tradíciók és a helyi meghatározottság, illetve az egyes városi centrumokban, régiókban megfigyelhető a történetileg kialakult klaszter-képződés. Ebből következöen a városhierarchia nagymértékben pénzügyi hierarchia is egyúttal, így a legtöbb országban számos regionális és egy-egy kiemelkedő nemzeti pénzügyi centrum található, amelyek közül néhány (New York, London, Tokió) egyben vezető globális pénzügyi központ is. A globális pénzközpontokra jellemzőek a történelmi múltra visszatekintő pénzügyi tradíciók, illetve a pénzügyi tevékenységek agglomerálódása, specializált pénzügyi negyedek, építészeti specifikumok és a pénzte- 
remtés funkcióját kihangsúlyozó szimbólumok is jelen vannak (Wall Street, City of London, New York Stock Exchange, Bank of England Headquarter).

\section{2) Az intézményi struktúrák földrajza}

A különböző nemzeti bankrendszerek intézményi-szervezeti struktúrájának alakulását vizsgálja. Ugyanúgy, mint maga a kapitalista rendszer, az alapvető monetáris formák és kapcsolatok a legtöbb országban hasonlóan fejlödnek, de vannak eltérö nemzeti (társadalom és intézményspecifikus) sajátosságok, amelyek a történetileg eltérö módon fejlödö országok pénzrendszerének különbözö intézményi modelljeit magyarázzák. A legtöbb tanulmány a több évszázados múltra visszatekintő brit bankrendszer intézményrendszerének fejlődését, a regionális bankrendszernek a nemzeti, londoni központú, centralizált bankrendszerré történỏ átalakulását vizsgálta.

A vizsgálatok másik csoportja leginkább az Egyesült Államok bankrendszerének erôsen szabályozott, decentralizált intézményi struktúrájával foglakozik. Az 1927-es McFadden törvény tiltotta a bankok több államban való müködését (interstate banking), a Glass Steagall Törvény (1933) pedig törvényileg elválasztotta a kereskedelmi banki és a befektetési banki tevékenységet egymástól. Az amerikaihoz hasonló decentralizált és regionalizált banki struktúra Európa számos országára is jellemző (Németország, Franciaország, Olaszország, Lengyelország), s ezeket is számos tanulmány vizsgálta (Mazucca 1993; Preiß 1988; Stryjakiewicz-Potrzebowski 1995).

Az utóbbi évtizedben egyre fontosabb a pénzügyi rendszerek intézményföldrajzának a kutatása, hiszen az intézmények által szabott keretek egyben a helyi közösségek pénzmozgásait is befolyásolják. A helyi-regionális környezetbe beágyazott bankrendszerek erösebben regionális gazdaság függőek, s éppen ezért sokkal inkább szolgálják a helyi gazdaság érdekeit, mint a központból irányított országos bank helyi fiókjai. A regionális bankrendszer egyik célja a régió pénzügyi forrásainak helyben tartása, a kiáramlás megakadályozása lehet, ugyanakkor a regionális gazdaság sebezhetősége is nagyobb, a helyi bankok nehezebben állják a versenyt, érzékenyebbek a gazdasági recesszióra. A központi bank által irányított bankfiókhálózati rendszerben az országos hálózat nagyobb potenciálja védelmet nyújthat a helyi gazdaság recessziójával szemben, de a helyi bankoknak a központtól való erős függése és gyengébb teljesitménye is jellemző az erősen központosított szervezeti struktúra miatt. Ugyanakkor térségi recesszió idején elöször a periférikus régiók fiókhálózatának racionalizációja, bezárása kerül sorra.

\section{3) A pénzügyi terek szabályozásának földrajza}

A pénz története egyben a regulációk története is. A nemzetállamok egyik tradicionális funkciója a pénzforgalom és a nemzeti pénzrendszerek és intézményeik állandó szabályozása. Az állam egyfelöl meghatározza a nemzeti monetáris rendszer kulcselemeit, a kamatlábakat, deviza átváltási árfolyamokat, a hitelezés felügyele- 
tét, a kötelező tartalékrátát, a pénzkínálatot és a tőkemozgások ellenőrzését (korlátozását), másfelöl pedig szabályozzák a különböző pénzügyi intézmények hatáskörét, funkcióit és a piaci versenyt.

A szabályozott terek földrajzi variációi a lokálistól a globálisig terjednek. Az egyes bankrendszerek regulációs politikája nagymértékben függ az adott bakrendszer földrajzi dimenziójától. Az Egyesült Államokban a bankrendszer szabályozása (a hálózatfejlesztés, bankalapítás) az egyes tagállamok hatásköre. A nemzeti szintü szabályozás mellett azonban a nemzetközi pénzpiacok fejlődése már a múlt század második felében elengedhetetlenné tette a nemzetközi pénzmozgások valamiféle szabályozását. Az 1870-es években megteremtett és az 1920-as évek végéig funkcionáló nemzetközi aranystandard rendszer, majd az 1945 és 1973 között funkcionáló US \$ alapú Bretton Woods-i rendszer és intézményei (IMF, IBRD), a legutóbbi évtizedek baseli „valutafórumai”, valamint az Európai Monetáris Unió intézményiszabályozási rendszerei példázzák a globális méretủ pénzügyi szabályozás eddigi eredményeit. Megjegyzendö, hogy az említett szabályozott terek mindegyike egyben meghatározható földrajzi dimenziót is jelent.

A pénztőkék természetesen igyekeznek megszabadulni a szabályozás kötelékei alól, és az olyan kevésbé regularizált terek, pénzközpontok felé igyekeznek, amelyekben az állami beavatkozás a pénzpiaci mozgásokba minimális, az adók alacsonyak és a potenciális profit magasabb. A pénztőkék természetes térbeli mozgásfolyamatainak köszönhették az eurodollárpiacok virágzásukat az 1960-as évektől kezdődöen, majd az 1970-es években a különböző, specializált funkciójú off-shore pénzparadicsomai (Bahamák, Kajmán-szigetek, Csatorna-szigetek, Hong Kong).

\section{4) Az állam és a közszféra pénzügyi terei}

$\mathrm{Az}$ állam szerepe nem csak a pénzpiacok múködésének szabályozásában merül ki, de a nemzeti pénzrendszer irányításában, államközi együttmúködésekben való közremúködés is az állami feladatok közé tartozik a nemzetközi pénzpiacok szabályozását érintő kérdésekben. Az állami és közkiadások finanszírozásában a pénzpiac szereplöi aktívan közremúködnek, melynek jelentőségét a pénzpiacon keresztül finanszírozott állami kiadások drasztikus növekedése is jelzi (ez 1920-ban a GDP 10-15\%-át jelentette, ami az 1970-es évekre 30-50\%-ra duzzadt). A közszféra tehát napjainkra a pénzügyi szféra egyik legfontosabb szereplőjévé vált, így nem csak a kormányzati szintủ, de a regionális és a helyi pénzügyek, központi és helyi adórendszerek vizsgálata is meglehetős aktualitással bír.

\section{5) A pénz társadalmi terei}

A pénzpiacok nemcsak a gazdasági tér részét képezik, hanem maguk is a társadalmi viszonyok, interakciók és függöségi viszonyok által strukturáltak, hiszen a pénzpiaci szereplők a társadalom szerves részét képezik, akik érdek- és értékviszonyokat, viselkedési szabályokat, kooperatív és kompetitív képességeket jelenítenek meg. A személyes kontaktusok által megteremtett informális kapcsolatok még a 
virtualizálódó pénzkezelési csatornák és technikák ellenére is döntőek a pénzügyi tranzakciók és üzletek bonyolításában, így a földrajzi dimenzió továbbra is meghatározó. A pénzügyi mozgásfolyamatok és kötelezettségek komplex tér-idő hálózatai meghatározóak a mindennapi társadalmi folyamatok szempontjából is. A kapitalista gazdaságokban a pénz, illetve a pénzügyi eszközök birtoklása mind a társadalmi befogadás, mind pedig a társadalmi kirekesztés szempontjából meghatározó. A pénz birtoklása gazdasági és társadalmi erőforrásokhoz való hozzájutásunk mellett a fogyasztói tömegtársadalomban elfoglalt helyünket és rajta keresztül társadalmi és kulturális identitásunkat is meghatározza.

A legutóbbi évtizedben született pénzügyi földrajzi munkák egy jelentős hányada az üzleti és a pénzügyi szolgáltatások magas sürüségével jellemezhető pénzügyi központok társadalmi és kulturális szerkezetével, felépítésével foglalkozik (AminThrift 1992; Thrift 1994). A fenti attributumok legjellegzetesebben a hosszú ideje fennálló és folyamatosan múködő, a nemzetközi pénzügyi változásokhoz gyorsan alkalmazkodó nemzetközi pénzközpontok esetében vizsgálhatók. Ezeknek a kiemelkedő centrumoknak óriási szerepe van a pénzügyi információk közvetítésében, ami elsősorban a globális gazdaságot érintő információdömpinggel való megbirkózás szervezeti és informatikai kereteinek kiépítésében ölt testet. A nemzetközi pénzcentrumokban koncentrálódó információtömeg kezelése, a szakértők tömegeinek, magas szintü képzettséggel rendelkező pénzügyi szakembereknek a foglalkoztatását is megköveteli (Leyshon 1995). Mindezek a folyamatok alátámasztják azt a nézetet, miszerint a pénzügyi rendszer egy olyan idö-tér és információ által meghatározott tranzakciós hálózat, amelyben nemcsak a pénz - korábban kizárólagosan hangsúlyozott - funkciói, hanem a társadalmi viszonyok és kapcsolatrendszerek is meghatározóak. A pénzügyi rendszer - Thrift szerint - egy intézményesült kockázati környezetnek tekinthetö, amelyben a közremúködő aktorok egyik célja ezeknek a kockázatoknak a csökkentése a bizalom erösítése, az interperszonális kapcsolatok révén.

\section{A pénzügyi terek jelentősége az ezredfordulón}

A pénzföldrajz iránt jelenleg mutatkozó fokozott érdeklödés oka részben a pénzügyi rendszer gyökeres és globális méretü átalakulása, részben pedig az időnként bekövetkező globális kisugárzású globális válságoknak köszönhető, amelyek folyamatosan alakítják és átformálják a pénzügyi teret. Az újszerü vizsgálatok terjedésére ösztönzöen hatott O'Brien „end of geography” tézise, amely a globalizáció hatásainak következményeként a földrajzi hely szerepének leértékelödését, az állam regulációs szerepének csökkenését, mint a jelen uralkodó és egyedül jellemző tendenciáit vizsgálja (O'Brien 1992).

A pénzügyi földrajzi kutatások egy nagy kérdése a tér illetve a földrajzi hely, mint telepítỏ tényezỏ létjogosultságának a vizsgálata napjaink globalizálódó pénzpiacain, amikor is az információs technológiák nagymértékben kiszélesítették a pénzügyi 
intézmények földrajzi telephelyválasztásának lehetőségeit. A globális integráció és a lokális fogadókészség dichotómiája azonban a pénzpiacok területi aspektusaiban is jelen van.

$\mathrm{Az}$,end of geography” tézis képviselöi megfogalmazásában a pénzpiaci szereplök és intézményeik egy széleskörüen diszperz piacon tevékenykedhetnek sikeresen anélkül, hogy telephelyük földrajzi elhelyezkedésének különösebb jelentösége volna (Castells 1989; Harvey 1989; O'Brien 1992; Ohmae 1989; 1995). O'Brien megfogalmazásában a földrajzi hely jelentöségét vesziti napjainkban, ugyanis a pénzügyi szabályozók már nem képesek egy jól körülhatárolható terület (nemzetállam) feletti ellenőrzésre, a szabályozók nem a nemzetgazdaságok földrajzi kereteire, hanem „a területen kívüliséget élvező 'stateless money' keretéül szolgáló teljes globális térre" vonatkoztathatók. A pénzügyi szféra intézményei számára a telephelyválasztás lehetősége óriási mértékben kiszélesedett, a tözsdék nem képesek többé monopolizálni egy adott ország vagy régió vállalatainak részvényportfolióit, a fogyasztók számára pedig az „end of geography” koncepció a szolgáltatásoknak korábban soha nem látott - a tradicionális helyi bankok szolgáltatásain túlnövő kínálatát jelenti. A földrajzi távolság helyett az információ költsége a meghatározó. $\mathrm{Az}$ információhoz és a szolgáltatásokhoz való folyamatos 24 órás hozzáférés már napi valóság, a komputerizált kereskedésre történö átállással a vállalatok bárhol elhelyezkedhetnek a Földön, következésképpen a telepítési tényező szerepe nem dominál az üzleti döntésekben (O'Brien 1992). A nézet képviselöi szerint a földrajzi tényező és a lokációs faktorok szerepét az elektronikus pénzmozgás által formált kiegyenlített globális pénzügyi tér veszi át, amelyben a konvergenciák uniformizált globális pénzpiacok kialakulását, és a látszólag véletlenszerü eloszlású térbeli mozgások és áramlások megléte egy látszólag ellentétek nélküli, kiegyensúlyozott pénzügyi tér kialakulását eredményezheti. Az új rendszerben már nem a lokalitás, nem a távolság, csak az információs költség a meghatározó.

$\mathrm{Az}$,end of geography” elmélet megalkotói azonban eltúlozzák a pénzügyi globalizáció homogenizáló térbeli, politikai és gazdasági hatásait, és a globalizációt mintegy külsö, felülröl vezérelt folyamatként írják le, amely tudatosan és elkerülhetetlenül vezet a pénzügyi tevékenységek térbeli decentralizációjához és dekoncentrációjához (Martin 1999).

Valójában a pénzügyi vállalatoknál a decentralizációs és dekoncentrációs tendenciák dominanciájának ellentmondóan egyre inkább a pénzügyi szolgáltatások és intézményeik nagyfokú koncentrálódása és agglomerálódása figyelhető meg, tehát a dereguláció, az új technológiák és a globalizáció ugyanúgy koncentrálja az üzleti szolgáltatásokat, a szakértelmet a meglévő központokba, ahonnan már földrajzi távolságra tekintet nélkül könnyen elérhetők az ügyfelek. A pénzpiacok koncentrációi egyre inkább a globális (és nemzetállami) térben elhelyezkedö, abból kiemelkedö, globális funkciókkal rendelkező világvárosi-nagyvárosi agglomerációkhoz kötödnek. Ezzel magyarázható a korábban is jelentös nagy pénzügyi központok (New York, Tokió, London) legföbb globális központokká válása, amelyek poziciójuknál fogva a legtöbb globális cég telephely preferenciájául szolgálnak. A világ 
pénzügyi központjai versenyben állnak egymással, a különböző telephelyek eltérő versenyfeltételei mind erősítik az egyes központoknak a lokalitás (agglomerálódás) előnyeiből fakadó versenyelỏnyeik és üzleti pozíciójuk megerősitésére irányuló törekvéseit. A pénzügyi központok jelentőségét tovább növeli, hogy itt vannak a legfontosabb pénzpiacok, s itt születik döntés a világ pénzkészleteinek felhasználásáról.

Mindez csak megerösíti azoknak az elképzeléseit, akik szerint a koncentrációs és decentralizációs folyamatok továbbra is jellemzik a pénzügyi teret, ez a kettősség a pénzügyi globalizáció dialektikus jellemzője, következésképpen a telephelyválasztás a pénzügyi szférában mind a nemzeti, mind pedig a globális pénzpiacokat meghatározó fontos tényezö marad (Laulajainen 1998). A pénzügyi globalizáció tehát messze nem egy autonóm, térbeliséget nélkülöző, felülröl vezérelt rendszer, hanem egy olyan földrajzilag meghatározott folyamat, amely egy bizonyos földrajzi helyen elhelyezkedő vállalatok, intézmények és hatóságok szervezeti, technológiai, regulatív és vállalati stratégiáinak az együttes terméke (Martin 1999). A globalizáció felemésztheti a teret, de semmi esetre sem áshatja alá a földrajzi helynek, a lokalitásnak a jelentöségét. Castells megfogalmazásában a helyek tere (space of place) fogalom helyett a térbeli áramlások terei (space of flows) lesznek meghatározóak, azonban bizonyos tradicionálisan is kedvezỏ pozícióban lévő központok ezeknek az áramlásoknak kiemelkedö információs és „elosztó”csomópontjaiként továbbra is meghatározó szerepet játszanak, így a földrajzi lokalitás jelentősége nagyobb, mint korábban bármikor (Castells 1989).

1) A földrajzi tér és a lokalitás földrajza központi jelentőségủ marad továbbra is, azonban inkább a relatív földrajzi helyzet és nem a korábban fontos megközelíthetőség, közelség a lényeges tényező, hanem a virtuális és a valós térben való kapcsolatteremtö és hálózatépítő képesség (Bernek 1999).

2) Az egyensúly közgazdasági törvényei szerint müködö gazdaság neoklasszikus víziójában a tökéletesen müködő, szabályozásmentes és egyensúlyi állapotú tökepiacokkal szemben még a pénzmozgás és az akkumuláció erős differenciái figyelhetök meg, így a tökealapok továbbra is a nagyobb növekedést és hozamot biztosító országokban, régiókban koncentrálódnak, ezzel is növelve a területi egyenlötlenségeket. A globális pénzpiaci integráció inkább a tökében gazdag illetve szegény észak-dél ellentétek elmélyülését, azaz egy globális aszimmetriát konzervál, tehát a globalizáció nem csökkentette a fejlödési szakadékot, hanem inkább növelte azt a pénzügyi szférában is.

3) A globalizáció azonban nem rendelkezik korlátlan hatalommal, a nemzetállamok szuverenitása jelenti befolyásának legnagyobb korlátját, továbbra is nemzetenként eltérőek a valuták és a bankrendszerek. A pénzkínálat szabályozása továbbra is a nemzetállami gazdasági szuverenitás kvinteszenciája maradt, bár az államok erös pénzpiaci kihívással állnak szemben. A pénzügyi válságok globális interdependenciák hatására, de nemzetállami keretek között exkalálódnak, és ha a piac beavatkozást igényel, akkor - globális felügyeleti rendszerek és intézmények hiányában - az is a nemzetállami intervenció és reguláció formájában jelentkezik. 
4) A lokális szinten lévő differenciák globális szinten a pénzpiaci szereplők költségminimalizálását szolgálják. A rövid ciklusú kamatráták kiegyenlítödése nem járt együtt a profitráták kiegyenlítődésével, ami továbbra is jelentős különbségeket mutat még a vezetö kapitalista országokon belül is. Ugyanakkor a tőke nem mindig a legnagyobb megtérülést, profitot biztositó térségek felé mozog, csak a biztonságos hitelfelvevők és befektetések dominálnak, a rizikósabb befektetési területen általában plusz díjtételek felszámítása a jellemző.

5) A globalizáció nem szünteti meg a földrajzi tér, a pénzpiaci tér jelentőségét, de folyamatosan átalakítja azt. Ezeket az állandó átalakulásokat, mozgásokat az ismétlődő pénzpiaci krízisek generálják. A pénzügyi válságok eltéróen érintik az egyes központokat, bankrendszereket, a válságokban a helyi adottságok is meghatározóak, hiszen egy helyi válság a meglévö interdependenciák folytán az egész Földön végig söpör, de különbözőképpen sújtja az egyes érintett térségeket, országokat és régiókat. Az 1998-as pénzügyi válság tapasztalatai azt is megmutatták, hogy a deregulázott világban a válságok nagyobb földrajzi instabilitással járnak (Kelet-Ázsia rossz felügyeleti rendszerei). A krízisérzékeny pénzpiaci szereplök magatartását is az állandó térbeli mozgékonyság jellemzi. A globális pénzpiacok csomópontjai, a nemzetközi pénzközpontok formálják és ellenőrzik a globális pénzügyi teret, s mintegy deregulatív földrajzi menedékként szolgálnak a tőkemozgások számára az adott nemzetállamokon belül. Ugyanakkor ezek a központok maguk is állandó kölcsönhatásban fejlődnek az adott nemzetállammal, amelyben elhelyezkednek.

6) A nemzetközi pénzpiacok növekvő instabilitása mellett a költségminimalizálásra és a profitmaximalizálásra való állandó törekvés egyre erôsödő versenyt gerjesztő hatásai a pénzpiaci folyamatok egyre több területén éreztetik hatásukat:

- Egyre specializáltabb szolgáltatások, új termékek és az egyre gyorsabb információs reagálási igény növekedése.

- Nem-pénzügyi cégek is megjelennek a pénzügyi piacon (nyugdíjalapok), s a pénzpiaci szereplök is új, számukra addig ismeretlen piaci szegmenseken szállnak versenybe, ezzel növelve a pénzpiaci dekoncentrációt.

- Az erősödő piaci verseny hatására a versenypozíciók és a piac megszerzése céljából a felvásárlások és fúziók révén nő az intézményi és a piaci koncentráció. A felvásárlás - nemzeti és nemzetközi szinten egyaránt - nem csak a helyi, regionális bankok beolvasztását, de a nagyok fúzióit, „nagytérségi bankok" kialakulását, s egyes esetekben pedig eltérő profilú cégek, adott esetben banki és biztosítótársaságok, befektetési alapok összeolvadását, ún. szuperkoncentrációk kialakulását eredményezheti.

- A globális pénzközpontokban a külföldi bankok erős koncentrálódása jellemző. Amíg az 1970-es évek elején Londonban 159, New Yorkban 75, Tokióban pedig csak 60 külföldi bank települt, addig 1995-re Londonban 520-ra, New Yorkban 340-re, Tokióban pedig 90-re nőtt a külföldi bankok száma (Martin 1999). A koncentrálódás célterülete mindig jellemzően ki- 
választott nemzetközi központ, amely erős specializációjával, munkaerökínálatával, üzleti szolgáltatások agglomerálódásával, társadalmi, gazdasági és a megteremtett iuzleti környezetével egyuitt multiplikátorként vonzza a többi intézménytípust is. Mindez ellentmond az ,end of geography”, tézis képviselöinek, ugyanis azt bizonyítja, hogy a nemzetközi cégek preferálják a nagy nemzetközi pénzügyi központokban történő együttes megtelepedést. Ezáltal biztosítják a maguk számára mindhárom/négy világgazdasági eröcentrumban való jelenlétet és a specializálódott funkciók ellátása számára a legmegfelelőbb nemzetközi telephelyet. A földrajzi tényező szerepe a speciális piacokon való megtelepedésnél, a központok speciális ådottságainak, a lokalitásból adódó versenyelőnyeinek és a kedvező agglomerációs hatások kihasználásánál tehát továbbra is döntö tényező a pénzpiaci szereplök számára (Martin 1999).

A világgazdaságra jellemző dialektikus egységben szerveződó egymással ellentétes fejlődésú tényezők (homogenizáció-differenciáció; integráció-dezintegrációregionalizálódás; centralizáció-decentralizáció; koncentráció-agglomerálódás-dekoncentráció) együttes jelenléte a földrajzi tér formálásában a legfőbb jellemző. A különböző pénzügyi terek - nemzeti, globális, regionális, lokális - együttesen léteznek, kölcsönös egymásra hatásuk elfogadott tény. Mint a fentiekböl kiderült a pénzügyi szolgáltatások számára továbbra is meghatározó a térbeli elhelyezkedés és a lokalitás, amiből következően a szolgáltatások elérhetősége a térben eröteljesen különböző. A pénzügyi globalizáció tehát nem autonóm, térbeliséget nélkülöző, felülről vezérelt rendszer, hanem a földrajzilag meghatározott helyen elhelyezkedő vállalatok, intézmények szervezeti, regulatív és vállalati stratégiáinak egyuuttes terméke. A földrajzi hely speciális piaci és egyéb adottságaiból származó versenyelönyök, agglomerációs és multiplikátor hatások kihasználásának továbbra is döntö szerepe marad.

A globalizáció mellett a nemzeti és még inkább a regionális gazdaságok szerepe továbbra is meghatározó, bizonyos monetáris tényezők (profitráták térbeli differenciái) területi különbségei továbbra is kikényszerítik a nemzeti és regionális pénzpiacokkal való behatóbb vizsgálódásokat.

\section{Irodalom}

Alessandrini, P. (1992) Squilibri Regionali e Dualismo Finanzario in Italia: Alcune Riflessioni. - Moneta Credito. 177. 6-81. o.

Alessandrini, P.-Zazzaro, A. (1999) A „Possibilist” Approach to Local Financial Systems and Regional Development: The Italian Experience. Money and the Space Economy. - Martin, R.(ed.), Chichester, John Wiley \& Sons. 71-92. o.

Amin, A.-Thrift, N. (1992) Neo-Marshallian Nodes in Global Networks. - International Journal of Urban and Regional Research. 16.571-587. 0.

Bernek Á. (1999) A globális világ politikai fơldrajzi kérdései, avagy a politika és a gazdaság összefonódása a globális világgazdaságban. Változó világ, átalakuló politikai fóldrajz. Első magyar politikai földrajzi konferencia. Pécs, 21-27. o.

Castells, M. (1989) The Informatinal City. Oxford, Basil Blackwell.

Central Europe's Largest Banks. (1999) - Central European Economic Review. October. 7. 
Chick, V.-Dow, S. (1988) A Post-Keynesian Perspective on the Relation Between Banking and Regional Development. Post-Keynesian Monetary Economics. - Arestis, P. (ed.), Aldershot, Edward Elgar. 219-250. 0 .

Chick, V. (1993) The Evolution of the banking system and the Theory of Monetary Policy. Monetary Theory and Monetary Policy,: New Tracks for 1990s. - Frowen, S. (ed.), London, Macmillan.

Cohen, S.-Maeshiro, A. (1977) The Significance of Money at the State level. - Journal of Money, Credit and Bankin. 9.674. o.

Conzen, M.P. (1979) The Maturing Urban System In the US. 1840-1910. Geografic Perspectives on America's Past. - Ward, D. (ed.), New York, Oxford, University Press. 253-274. o.

Corbridge, S.-Martin R.-Thrift, N. (eds.) (1994) Money, Power and Space. Oxford, Blakwell.

Dow, S. (1987) Money and regional Development. - Studies in Political Economy. 23, 732-794. 0.

Dow, S. (1988) Incorporating Money in Regional Economic Models. - Papers in Regional Science. 19. London, Pion.

Dow, S. (1990) Financial Markets and Regional Economic Development: The Canadian Experience. Aldershot, Avebury.

Harvey, D. (1974) Social justice and the City. Oxford, Basil Blackwell.

Harvey, D. (1982) Limits to capital. Oxford, Basil Blackwell.

Harvey, D. (1989) The Conditions of Postmodernity. Oxford, Basil Blackwell,

James, J. (1976) Banking Market structure, Risk and the pattern of Local Interests Rates in the USA, 1893-1911. - Journal of Economoic History. 36. 112-130. o.

Laulajainen, R. (1998) Financial Geography-Departments of Geography. 93. Goteborg, Series of Gothenburg University. School of Economics and Commercial Law.

Lee, R. (1993) Interurban Competition? Financial centres and the geography of financial production. International Journal of Urban and Regional Research. 17. 492-515. o.

Lee, R. (1999) Local Money: Geographies of Autonomy and Resistance? Money and the Space Economy. - Martin R. (ed.), Chichester, John Wiley \& Sons. 71-92. 0.

Leyshon, A. (1995) Geographies of money and finance I. - Progress in Human Geography. 19. 531-543. o.

Leyshon, A.-Thrift, N. (1997) Money/Space: Geographies of Monetary Transformation. London, Routledge.

Losch, A. (1954) The Economics of Location. New Haven, Yale University Press.

Martin, R. (1989) The Growth of Autonomy of venture capitalism in the UK. - Regional Studies. 23. 389-403. o.

Martin, R. (1994) Stateless Moneies, Global Financial Integration and National Economic Autonomy: End of Geography? Money, Power and Space. - Corbridge, S.-Thrift, N.-Martin, R. (eds.), OxfordCambridge, Blackwell.

Martin, R. (1999) The New Economic Geography of Money. Money and the Space Economy - Martin R. (ed.), Chichester, John Wiley \& Sons. 207-224. o.

Mazucca, R. (1993) A bankhálózat területi szervezete Olaszországban. (The spatial structure of the banking network in Italy). Régiók és városok az olasz modernizácioban. - Horváth Gy. (szerk.), Pécs, MTA RKK. 307-317. 0.

McKillop, D.G.-Hutchinson, R.W. (1991) Financial Intermediaries and Financial Markets: A United Kingdom Regional Perspective. - Regional Studies. 25. 543-554. o.

Moore, C.-Hill, J. (1982) Interregional arbitrage and the supply of loanable funds. - Journal of Regional Science. 22. 499-512. o.

Myrdal, G. (1956) An international economy: problems and prospects. New York, Harper \& Brothers.

O'Brien (1992) Global Financial Integration: the end of Geography. London, Pinter.

Ohmae, K. (1989) The Borderless World. Cambridge, Mass. Harvard Business Review Books.

Ohmae, K. (1995) The Evolving Global Economy. Cambridge, Mass. Harvard Business Review Books.

O'Uallachain, B. (1994) Foreign Banking in the American Banking system of Financial Organization. Economic Geography. 70. 206-228. o.

Porteous, D. (1995) The Geography of Finance. Aldershot, Avebury.

Preiß, A. (1988) Banken und regionalstruktur II., Banken und Sparkassen als Partner kleiner und mittlerer Unternehmen im peripheren Raum Oberfranken. - Arbeitsmaterialen zur Raumordnung und Raumplanung. Heft 68. Universitat Bayreuth.

Roberts, R.B.-Fishkind, H. (1979) The role of monetary forces in regional economic activity: an Econometric Analysis. - Journal of Regional Science. 19. 15-29. o.

Rockoff, H. (1977) Regional Interst Rates and Bank Failures, 1870-1914. - Exploration in Economic History. 14. 76-91. o.

Sassen, S. (1991) The Global City. Princetown, University Press. 
Stryjakiewicz, T.-Potrzebowski, G. (1995) The newly emerging banking system in Poland and its Spatial Organisation. - Geographische Zeitschrift. 2. 87-99. o.

Thrift, N. (1994) On the social and cultural determinants of international financial financial centers. Money, Power and Space. - Corbridge, S.-Martin, R.-Thrift, N. (eds.), Ox ford, Blakwell.

Thrift, N.-Olds, K. (1996) Reconfiguring economic in Economic Geography. - Progress in Human Geography. 20. 311-337. o.

Tickell, A. (1996) Taking the initialive: The Leeds financial centre. Corporate City? - Haughton, G.Williams, C. (eds.), Brookefield, Avebury. 103-118. o.

Zazzaro, A. (1997) Regional banking System, Credit Allocation and Regional Economic Development. Economie Appliquée. 31. 51-74. o.

\section{THE NEW TREND OF REGIONAL SCIENCE: FINANCIAL GEOGRAPHY}

\section{ZOLTÁN GÁL}

The ever-greater interest in the geography of finances is justified by the booming growth in financial services and information technology, and also those significant changes and financial crises which do not only shape the financial space but also continuously form the financial map of the world. The extremely strong space-forming processes going on these days in the world economy which is showing a definite monetary character, and the real activities unbelievably appreciated to the detriment of the real economic sphere, also the income transfers on the international financial market and among the national economies all justify the geographical and regional economic survey of the financial processes. 